\title{
Sosialisasi Upaya Pencegahan dan Penanggulangan Bahaya Kebakaran di Sekolah Luar Biasa (SLB) Kota Balikpapan
}

\author{
Siska Ayu Kartika ${ }^{1 *}$; Agung Prabasworo' ${ }^{1}$ Abdy Nugroho ${ }^{1}$ \\ 1*Program Studi Teknik Mesin, Fakultas Teknologi Industri, Universitas Balikpapan \\ 1*siska.ayukartika@uniba-bpn.ac.id
}

\begin{abstract}
Abstrak
Secara umum, faktor utama banyaknya korban jiwa, kerusakan, dan kerugian yang timbul akibat bahaya kebakaran adalah masih kurangnya pemahaman dan kesadaran masyarakat, terutama mengenai bagaimana pencegahan dan penanggulangan bahaya kebakaran. Kebakaran gedung diakibatkan oleh listrik sering terjadi. Kebakaran tersebut diakibatkan beberapa hal seperti : instalasi yang tidak sesuai standar, penggunaan stop kontak menumpuk, pemeliharaan instalasi kurang teratur, umur instalasi melebihi standar. Salah satu upaya mendasar untuk meningkatkan kewaspadaan dan kesadaran menumbuhkan budaya siaga adalah dengan melakukan kegiatan sosialisasi, dan latihan kesiapsiagaan. Pelaksanaan sosialisasi dan latihan kesiapsiagaan yang dilaksanakan secara khusus, juga melibatkan kelompok rentan, seperti para penyandang disabilitas dan orang berkebutuhan khusus. Sehingga dipandang perlu dalam pelaksanaan pengabdian kepada masyrakat kali ini untuk melakukan sosialisasi upaya pencegahan dan penangggulangan bahaya kebakaran kepada seluruh tenaga pengajar, petugas sekolah dan seluruh siswa Sekolah Luar Biasa Kota Balikpapan. Pelaksana kegiatan sosialisasi ini dilaksanakan di bulan April 2017. Kerjasama antar tim pengabdian kepada masyarakat Universitas Balikpapan dan SLB Kota Balikpapan sangat baik sehingga upaya untuk meningkatkan pemahaman para guru dan siswa/siswi mengenai upaya-upaya yang dapat dilakukan untuk pencegahan dan penanggulangan bahaya kebakaran dapat berjalan dengan baik.
\end{abstract}

Kata Kunci: sosialisasi, pencegahan, penanggulangan, kebakaran

\begin{abstract}
In general, the main factor of the many casualties, damage and losses arising from fire hazard is the lack of understanding and awareness of the community, especially regarding how to prevent and deal with fire hazards. Building fires caused by electricity often occur. The fire was caused by several things such as: non-standard installation, stacking of electrical outlets, improper installation maintenance, exceeded standard installation life. One of the fundamental efforts to increase awareness and awareness to foster a culture of alert is to conduct socialization activities, and preparedness exercises. The implementation of special awareness raising and preparedness exercises also involves vulnerable groups, such as persons with disabilities and people with special needs. So that it is deemed necessary in the implementation of community service this time to socialize efforts to prevent and combat fire hazards to all teaching staff, school officials and special case students in SLB Balikpapan. The program was held in April 2017. Cooperation between the community service teams at the University of Balikpapan dan SLB Balikpapan were very good so that efforts to increase the understanding of teachers and students regarding the efforts that could be made to prevent and overcome the danger of fire could proceed well.
\end{abstract}

Keywords: socialization, preventive, recovery, fire hazard

\section{Pendahuluan}

Semua orang mempunyai risiko terhadap potensi bahaya kebakaran, sehingga penanganan bahaya kebakaran merupakan urusan semua pihak (everybody's business). Oleh sebab itu, perlu dilakukan berbagi peran dan tanggung jawab (shared responsibility) dalam peningkatan kesiapsiagaan di semua tingkatan, baik anak, remaja, dan dewasa.

Secara umum, faktor utama banyaknya korban jiwa, kerusakan, dan kerugian yang timbul akibat bahaya kebakaran adalah masih kurangnya pemahaman dan kesadaran masyarakat serta pelaku pengelola lingkungan terhadap risiko bahaya kebakaran di wilayahnya. Selain itu, dukungan mitigasi struktural yang belum memadai juga menjadi faktor tak terpisahkan. Hal ini mengakibatkan kesadaran, kewaspadaan, dan kesiapsiagaan dalam menghadapi bahaya kebakaran masih sangat kurang.

Masyarakat sebagai elemen utama yang merasakan suatu bencana harus mempunyai kemandirian dalam menghadapi bencana, sebab kerugian yang ditimbulkan oleh suatu bencana alam 
ataupun non alam sangat ditentukan oleh kesiapan, pengetahuan dan keterampilan yang dimiliki oleh masyarakat (Martanto, Aji, \& Parman, 2017).

Faktor yang paling menentukan adalah penguasaan pengetahuan yang dimiliki oleh "diri sendiri" untuk menyelamatkan dirinya dari ancaman risiko bahaya kebakaran. Kemudian, diikuti oleh faktor bantuan anggota keluarga, teman, bantuan Tim Sar, dan di sekelilingnya. Maka, edukasi untuk meningkatkan pemahaman risiko berdesain pencegahan dan penanggulan bahaya kebakaran merupakan pesan utama bersama yang akan didorong dalam proses penyadaran (awareness) dalam peningkatan kemampuan diri sendiri.

Proses penyadaran tersebut berguna agar setiap orang dapat memahami risiko, mampu mengelola ancaman dan, pada gilirannya, berkontribusi dalam mendorong ketangguhan masyarakat dari ancaman bahaya kebakaran. Di samping itu, kohesi sosial, gotong royong, dan saling percaya merupakan nilai perekat modal sosial yang telah teruji dan terus dipupuk, baik kemampuan perorangan dan masyarakat secara kolektif, untuk mempersiapkan, merespon, dan bangkit dari keterpurukan akibat bahaya kebakaran.

Salah satu upaya mendasar untuk meningkatkan kewaspadaan dan kesadaran menumbuhkan budaya siaga adalah melalui latihan kesiapsiagaan. Jenis-jenis latihan kesiapsiagaan yang dapat dilakukan antara lain (i) Aktivasi Sirine Peringatan Dini, (ii) Latihan Evakuasi Mandiri di Sekolah/Madrasah, Rumah Sakit Siaga Bahaya kebakaran, gedung bertingkat, dan pemukiman. (iii) Uji Terap Tempat Pengungsian Sementara/Akhir se-Indonesia. Latihan kesiapsiagaan yang dilaksanakan secara khusus, juga melibatkan kelompok rentan, seperti anak-anak, kaum lansia dan tuna-wisma (homeless), para penyandang disabilitas dan orang berkebutuhan khusus (Supartini et al., 2017).

Penyandang disabilitas, menurut UU No. 8 Tahun 2016, adalah setiap orang yang mengalami keterbatasan fisik, intelektual, mental dan/atau sensorik dalam jangka waktu lama yag dalam berinteraksi dengan lingkungan dapat mengalami hambatan dan kesulitan untuk berpartisipasi secara penuh dan efektif dengan warga negara lainnya berdasarkan kesamaan hak. Ragam penyandang disabilitas menurut UU tersebut adalah:

a. Penyandang disabilitas fisik adalah terganggunya fungsi gerak, antara lain amputasi, lumpuh layuh atau kaku, paraplegi, celebral palsy (CP), akibat stroke, akibat kusta, dan orang kecil

b. Penyandang disabilitas intelektual adalah terganggunya fungsi pikir karena tingkat kecerdasan di bawah rata-rata, antara lain lambat belajar, disabilitas grahita dan down syndrome. c. Penyandang disabilitas mental adalah terganggunya fungsi pikir, emosi, dan perilaku, antara lain:

1) Psikososial, di antaranya skizofrenia, bipolar, depresi, anxietas dan gangguan kepribadian;

2) Disabilitas perkembangan yang berpengaruh pada kemampuan interaksi sosial, di antaranya autis dan hiperaktif.

d. Penyandang disabilitas sensorik adalah terganggunya salah satu fungsi dari panca indera, antara lain disabilitas netra, disabilitas rungu dan/atau disabilitas wicara.

Dalam kesiapsiagaan terhadap bahaya kebakaran ini, partisipasi aktif masyarakat memainkan peran paling penting. Idealnya, kegiatan penanggulan bencana yang efektif melaui tiga tahap. Pertama, pencegahan atau mitigasi dan kesiapsiagaan sebelum terjadi bencana. Kedua, penyelamatan pada saat terjadi bencana. Ketiga, rehabilitasi dan rekonstruksi pada pascabencana (Nasution, 2012).

Secara garis besar, tujuan diselenggarakannya Pengabdian Kepada Masyarakat dengan melakukan Sosialisasi Upaya Pencegahan dan Penanggulangan Bahaya Kebakaran di Sekolah Luar Biasa (SLB) Balikpapan agar para pihak sekolah dan siswa SLB dapat:

1) Memahami penyebab terjadinya bahaya kebakaran

2) Melakukan upaya-upaya pencegahan terjadinya bahaya kebakaran di SLB Balikpapan

3) Merencanakan upaya penanggulangannya dan melaksanakan latihan kesiapsiagaan, dalam rangka penanggulangan bahaya kebakaran, memadamkan kebakaran sendiri (jika memungkinkan), melakukan aktivasi sirine peringatan dini evakuasi di SLB (jika dibutuhkan).

\section{Teori Segitiga Api dan Kebakaran}

Api adalah reaksi kimia dari beberapa elemen yang mengalami reaksi pembakaran dan menghasilkan panas, cahaya, dan hasil reaksi kimia lainnya.

Segitiga api adalah elemen-elemen pembentuk api yang dirangkai dalam suatu segitiga yang menggambarkan proses terjadinya api. Elemenelemen tersebut jika bersatu dan dalam porsi tertentu maka akan menimbulkan reaksi kimia dan menghasilkan api (Iraniana, 2009).

Elemen-elemen dalam segitiga api yang merupakan elemen pembentuk api yaitu: 


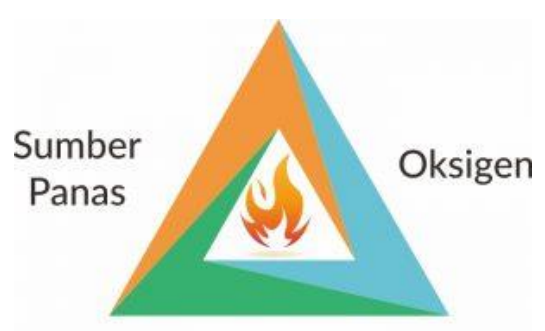

Bahan Bakar

\section{Gambar 1 Elemen segitiga api (sumber : handout training Basic Knowledge of Fire Protection)}

Bahan bakar yang dimaksud dalam gambar 1, adalah bahan-bahan yang mudah bereaksi dengan reaksi pembakaran atau bahan mudah terbakar. Bahan tersebut dapat berupa:

1. Zat padat: zat padat mudah terbakar contohya kertas, sampah kering, kayu, kain, dan lain-lain.

2. Zat cair: zat cair mudah terbakar contohnya minyak tanah, bensin, spirtus, alkohol, dan lainlain.

3. Zat gas: zat gas mudah terbakar contohnya karbit, LPG, dan LNG.

Ketiga bahan-bahan tersebut tentunya sudah tidak asing karena sering kita jumpai di kegiatan sehari-hari. Untuk itu penggunaan bahan-bahan mudah terbakar sebaiknya dijauhkan dari sumber panas atau api.

Sedangkan sumber panas yang dimaksud dalam Gambar 1, merupakan salah satu unsur terbentuknya api. Contoh sumber panas yaitu:

a. Faktor alam: seperti petir atau panas dari gunung berapi.

b. Energi panas listrik: panas listrik dapat timbul dari arus pendek, korsleting, percikan api karena listrik, pemanasan dielektrik seperti pada microwave (gelombang mikro), dan listrik statis.

c. Energi panas mekanis: panas mekanis dapat terjadi karena adanya gesekan atau

d. Energi panas kimia: contoh dari energi panas kimia yaitu reaksi panas pembakaran, panas akibat dekomposisi, panas larutan, dan pemanasan spontan.

e. Energi panas nuklir

f. Energi panas matahari

Di dalam udara yang kita hirup terdapat bermacam-macam unsur seperti nitrogen, argon, dan salah satunya adalah oksigen. Oksigen dengan kadar minimum $16 \%$ dapat menjadi unsur penting pembentuk api. Sedangkan dalam udara normal yang kita hirup terdapat kandungan 20\% oksigen. Sehingga pasokan oksigen idealnya sewaktu-waktu bisa mendukung terjadinya api.

Dari ketiga unsur tersebut akan terjadi reaksi kimia yang menyebabkan timbulnya api. Jika salah satu unsur dihilangkan maka api dapat dipadamkan. Dalam upaya pemadaman api dapat menggunakan bendabenda di sekitar seperti selimut, air, dan alat pemadam api (Iraniana, 2009).

Kebakaran adalah api yang tidak terkendali yang meluap dan menyebabkan kerugian. Kerugian yang ditimbulkan dari kebakaran yaitu kerugian jiwa, kerugian materi, menurunnya produktivitas, gangguan bisnis serta kerugian sosial. Salah satu diantaranya adalah banyaknya korban jiwa dari kalangan anakanak juga menjadi kerugian yang perlu mendapat perhatian. Untuk menekan kerugian yang ditimbulkan, dibutuhkan mitigasi bencana kebakaran yang baik. Mitigasi adalah serangkaian upaya mengurangi resiko dan dampak yang diakibatkan oleh bencana, baik melalui pembangunan fisik (mitigasi struktural) maupun penyadaran dan peningkatan kemampuan menghadapi ancaman bencana (mitigasi non struktural). Proses mitigasi sangat dipengaruhi oleh kelengkapan dan kesiapan self-readiness yang telah dilakukan oleh pemerintah. Selain itu, masyarakat juga menjadi pendukung yang sangat penting dalam melakukan mitigasi bencana kebakaran. Faktor-faktor yang mempengaruhi kesiapsiagaan tanggap darurat bencana kebakaran diantaranya adalah faktor fasilitas yang dimiliki suatu bangunan kaitannya dengan tanggap darurat bencana kebakaran serta sikap, pengetahuan dan pendidikan. (Ashari, Prastiwi, Annabila, Rahmadani, \& Kusuma, 2018).

Sifat dari kebakaran adalah cepat menyebar, panas, menghasilkan asap yang gelap dan mematikan dikarenakan berasal dari api.

Tahapan kebakaran dalam ruangan:

a. Suhu ruangan yang terbakar meningkat hingga $100^{\circ} \mathrm{C}$, bahkan ada yang sampai $600^{\circ} \mathrm{C}$

b. Dapat membakar pakaian dan kulit manusia.

c. Dalam waktu 5 menit ruangan yang terbakar akan terasa panas dan dalam waktu yang sangat singkat semua barang akan habis dilahap api.

d. Dalam waktu singkat api akan merebak ke seluruh bangunan dan melahap semua yang ada.

e. Akan keluar asap tebal yang memenuhi ruangan. Jika seseorang bernapas dalam keadaan asap tebal dan beracun, akibatnya orang tersebut menjadi pusing dan sesak napas bahkan kematian (Supartini et al., 2017).

Kesiapsiagaan menghadapi kebakaran harus dipahami masyarakat karena keselamatan nyawa harus menjadi prioritas utama. Maka, penting bagi setiap orang untuk memiliki keterampilan evakuasi mandiri.

Ada tiga faktor penyebab kebakaran pada umumnya, yaitu :

1. Kebakaran karena sifat kelalaian manusia, seperti : kurangnya pengertian pengetahuan 
penanggulangan bahaya kebakaran; kurang hatihati menggunakan alat dan bahan yang dapat menimbulkan api; kurangnya kesadaran pribadi atau tidak disiplin.

2. Kebakaran karena peristiwa alam, terutama berkenaan dengan cuaca, sinar matahari, letusan gunung berapi, gempa bumi, petir, angin dan topan.

3. Kebakaran karena penyalaan sendiri, sering terjadi pada gudang bahan kimia di mana bahan bereaksi dengan udara, air dan juga dengan bahan-bahan lainnya yang mudah meledak atau terbakar.

4. Kebakaran karena kesengajaan untuk tujuan tertentu, misalnya sabotase, mencari keuntungan ganti rugi klaim asuransi, hilangkan jejak kejahatan, tujuan taktis pertempuran dengan jalan bumi hangus (Tri et al., 2017).

\section{Sumber Bahaya Kebakaran}

Sumber-sumber yang dapat mendukung terjadinya kebakaran, antara lain :

a. Listrik, karena tidak berfungsinya pengaman, kegagalan isolasi, sambungan tidak sempurna, peralatan yang tidak sesuai standar. Permasalahan konsleting listrik disebabkan rendahnya pemahaman masyarakat mengenai instalasi listrik yang baik dan aman, rendahnya pengetahuan mengenai pemanfaatan peralatan listrik (Yuniarti, Setiawati, \& Majid, 2018).

Kebakaran dapat diakibatkan beberapa hal seperti : instalasi yang tidak sesuai standar, penggunaan stop kontak menumpuk, pemeliharaan instalasi kurang teratur, umur instalasi melebihi standar (Janardana, Wijaya, Budiastra, \& Sukerayasa, 2018).

Masalah utama dalam mempelajari kelistrikan adalah tidak terlihat dan tidak bisa diraba, bahkan kita tidak mau merabanya. Kita tahu ada listrik setelah melihat akibatnya, misal lampu menyala, kipas berputar, dan radio bersuara. Ada tiga bahaya yang diakibatkan oleh listrik, yaitu kesetrum (sengatan listrik), panas atau kebakaran, dan ledakan. Kesetrum atau sengatan listrik akan dirasakan jika arus listrik melalui tubuh kita. Biasanya arus akan mulai dirasakan jika arus yang mengalir lebih dari $5 \mathrm{~mA}$. Pada arus yang kecil, aliran arus hanya akan mengakibatkan kesemutan atau kehilangan kemampuan untuk mengendalikan tangan. Pada arus yang besar, arus listrik bisa membakar kulit dan daging kita. Yang paling bahaya adalah jika arus tersebut mengalir melalui jantung atau otak. Perlu dicatat bahwa yang membahayakan adalah aliran arus listrik, bukan tegangan listrik. Walaupun tegangannya tinggi, bisa saja tidak membahayakan asalkan arusnya sangat kecil. Bahaya kedua adalah panas atau kebakaran. Panas muncul karena adanya aliran arus melalui suatu resistansi. Besarnya panas sebanding dengan kuadrat arus, besarnya resistansi, dan waktu. Jika kita menggunakan kabel yang terlalu kecil maka resistansinya besar. sehingga kawat bisa mengalami pemanasan. Kawat yang panas bisa menyebabkan terbakarnya isolasi kabel sehingga mengakibatkan terjadinya hubung singkat. Kontak atau sambungan tak sempurna juga bisa menyebabkan timbulnya panas yang membakar isolasi kabel. Menutup lampu, menutup kipas angin, menutup layar komputer dengan bahan yang mudah terbakar juga membahayakan. Bahaya ketiga adalah ledakan. Saat terjadi hubungsingkat, arus listrik yang mengalir akan sangat besar. Arus yang sangat besar bisa menyebabkan kenaikan temperatur yang sangat cepat sehingga menyebabkan naiknya tekanan udara secara cepat. Untuk instalasi perumahan, bahaya ini mungkin tidak terlalu besar karena arus hubung singkat yang mungkin terjadi tidak terlalu besar (Darmana et al., 2018)

b. Rokok, karena merokok ditempat yang terlarang, membuang puntung rokok sembarangan.

c. Gesekan mekanik, karena timbulnya panas karena kurang pelumasan pada bagian peralatan atau mesin berputar.

d. Pemanasan lebih, karena pesawat pengering tidak terkontrol.

e. Api terbuka, karena penggunaan api di tempattempat yang terdapat bahan mudah terbakar.

f. Permukaan panas, akibat kontak langsung instalasi atau peralatan yang tidak terlindungi.

g. Letikan bara pembakaran, karena buangan api dari knalpot motor diesel atau kendaraan angkutan.

h. Mekanikal spark (bunga api mekanik), karena letikan bunga api dari mesin gerindra.

i. Pengelasan, pekerjaan pengelasan aatu pemotongan dengan las.

j. Reaksi kimia, akibat reaksi yang terjadi dari unsur kimia (Iraniana, 2009).

\section{Klasifikasi Kebakaran}

Menurut Peraturan Menteri Tenaga Kerja No. Per 04 /MEN/1980 kebakaran diklasifikasikan menjadi 4 kelas, seperti yang terlihat pada gambar 2 :

a. Kebakaran kelas A, adalah kebakaran dari jenis bahan padat kecuali logam. Kelas ini mempunyai ciri jenis kebakaran yang meninggalkan arang dan debu. Unsur bahan yang terbakar biasanya mengandung karbon. Aplikasi pemadam yang cocok adalah bahan jenis basah yaitu "AIR". Prinsip kerja air dalam memadamkan api adalah menyerap kalor atau panas dan dapat menembus bagian dalam.

b. Kebakaran Kelas B, adalah jenis kebakaran dari jenis air dan gas. Kelas ini terdiri dari unsur bahanbahan yang mengandung hydrocarbon dari produk 
minyak bumi dan turunan kimianya. Aplikasi media pemadam yang cocok untuk bahan cair adalah bahan dari jenis "BUSA". Prinsip kerja busa dalam memadamkan api adalah menutup permukaan cairan yang akan mengapung pada permukaan. Aplikasi media pemadam yang cocok untuk bahan gas adalah jenis bahan pemadam yang bekerja atas dasar substitusi oksigen atau memutuskan reaksi berantai yaitu jenis "tepung kimia kering atau gas $\mathrm{CO}_{2}$ ".

c. Kebakaran Kelas C, adalah kebakaran pada listrik yang bertegangan. Aplikasi media pemadam yang cocok untuk kelas $\mathrm{C}$ adalah bahan jenis kering yaitu "tepung kimia kering dan gas $\mathrm{CO}_{2}$ ".

d. Kebakaran Kelas D, adalah kebakaran dari bahan logam. Pada prinsipnya semua benda dapat terbakar termasuk logam, hanya tergantung nilai titik nyalanya. Kebakaran logam memerlukan pemanasan awal yang tinggi dan akan menimbulkan temperatur yang sangat tinggi pula (Kementerian Tenaga Kerja dan Transmigrasi, 1980).

Jenis Alat Pemadam Kebakaran Ringan (APAR) dapar dilihat pada gambar 3 dan 4.

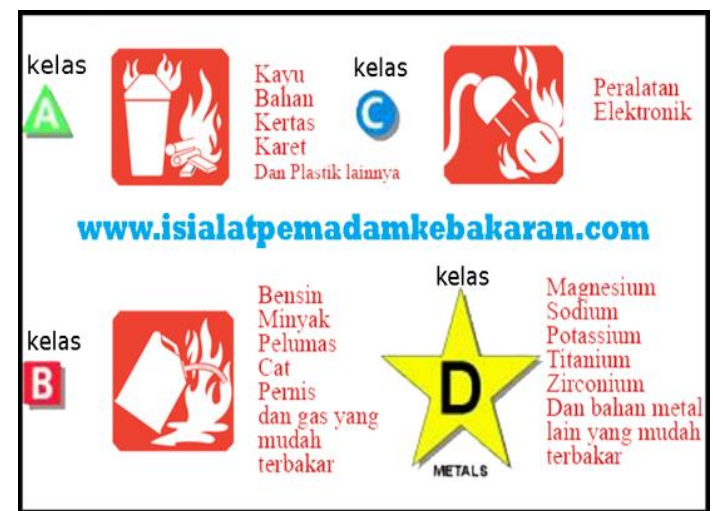

Gambar 2 Klasifikasi kebakaran (sumber : https://alatpemadamapi101.com)

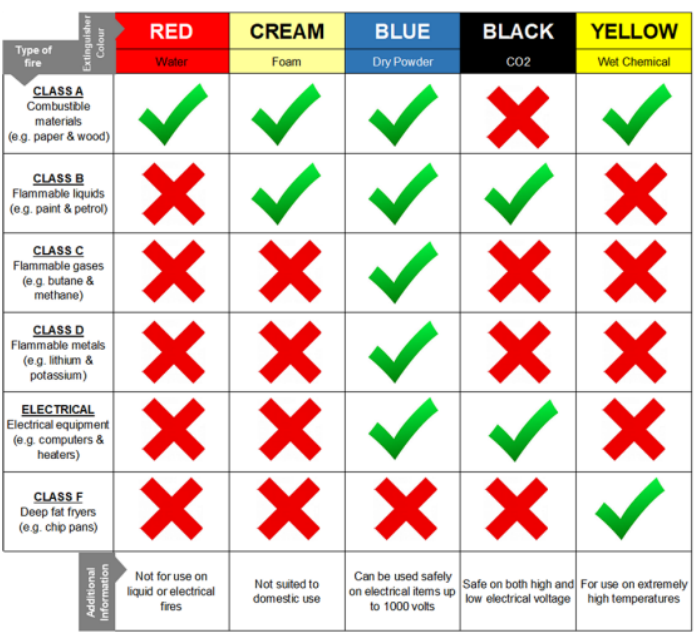

Gambar 3 Jenis alat pemadam kebakaran berdasarkan klasifikasi kebakaran (sumber : https://hsepedia.com/2018

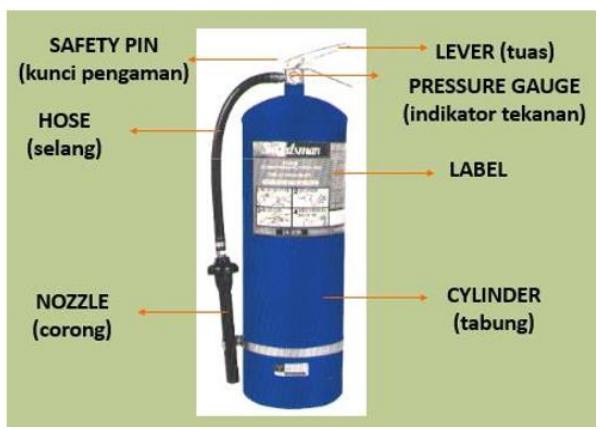

Gambar 4 Alat Pemadam Api Ringan (APAR) dan bagian-bagiannya (Handoko et al., 2017)

\section{Tindakan Pencegahan}

Aspek ini adalah yang paling langsung dan efektif dalam mencegah datangnya kebakaran. Pencegahan dan pembatasan perkembangan api, harus dimulai misalnya dengan :

a. Lakukan pemeriksaan rutin (yang sederhana secara visual) untuk alat-alat listrik yang digunakan. Tanda peringatan sederhana, misalnya :

- Bau gosong/terbakar pada kabel listrik

- Soket listrik menjadi hangat/panas

- Indikator pada beberapa peralatan listrik menyala redup

- Sirkuit breaker sering “trip"atau terputus

b. Hindari penggunaan alat-alat listrik yang tidak aman, seperti telrihat pada gambar 5 .

c. Lakukan pemeriksaan instalasi listrik rumah oleh tenaga professional (misal : dari PLN). Penggunaan alat-alat listrik yang aman dapat dilihat pada gambar 6 .

d. Perhatikan penggunaan peralatan listrik ditempat yang terkena air, misal kamar mandi, tempat cuci.

e. Matikan peralatan listrik yang tidak digunakan 
f. Gunakan lampu emergency pada saat mati listrik, jika memang harus menggunakan lilin, tempatkan pada alas yang aman dan tidak mudah jatuh, serta jauh dari bahan-bahan yang mudah terbakar

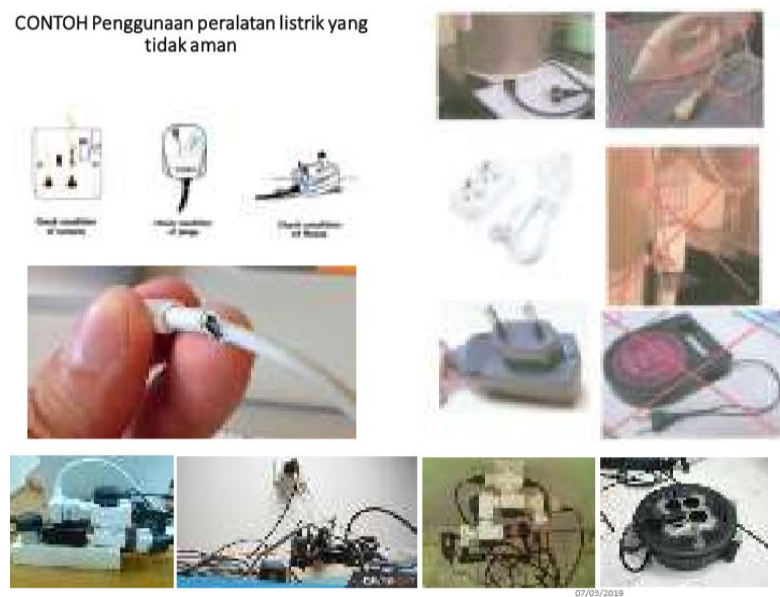

Gambar 5 Contoh penggunaan alat listrik yang tidak aman (sumber : Materi Sosialisasi Pencegahan Bahaya Kebakaran di perumahan TI, 2010)

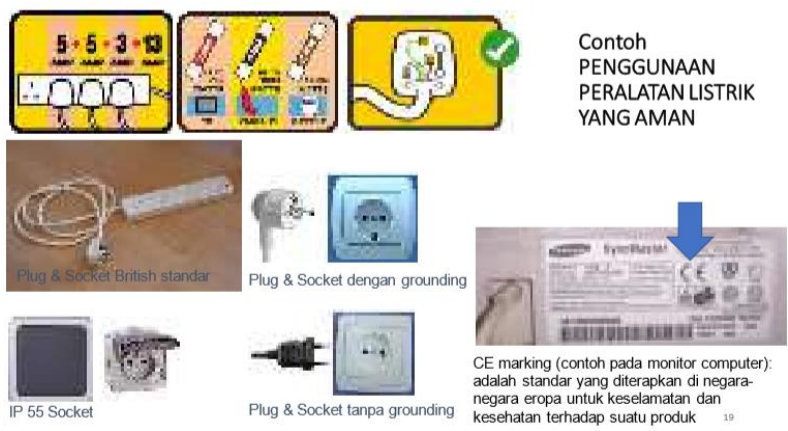

Gambar 6 Contoh penggunaan alat listrik yang aman (sumber : Materi Sosialisasi Pencegahan Bahaya Kebakaran di perumahan TI, 2010)

\section{Upaya Penanggulangan Kebakaran}
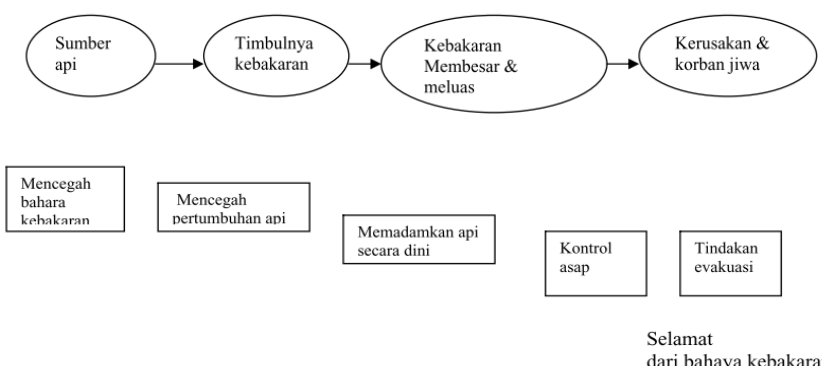

Gambar 7 Skema tahap penganggulangan kebakaran (Rahman, 2004)

Skema pada gambar 7, menggambarkan bahwa ada lima tindakan yang harus dilakukan sebelum tingkat bahaya api tidak dapat tertanggulangi lagi, yaitu :

a. Mencegah timbulnya kebakaran, dengan mewaspadai sumber-sumber api

b. Mencegah pertumbuhan api, desain kompartemen dan penggunaan material yang resisten. c. Memadamkan api secara dini, sistem proteksi aktif berupa pendeteksi dini dan sistem penyemprot, seperti terlihat pada gambar 8 .

d. Melakukan tindakan evakuasi, jalur evakuasi vertikal horizontal (Rahman, 2004).

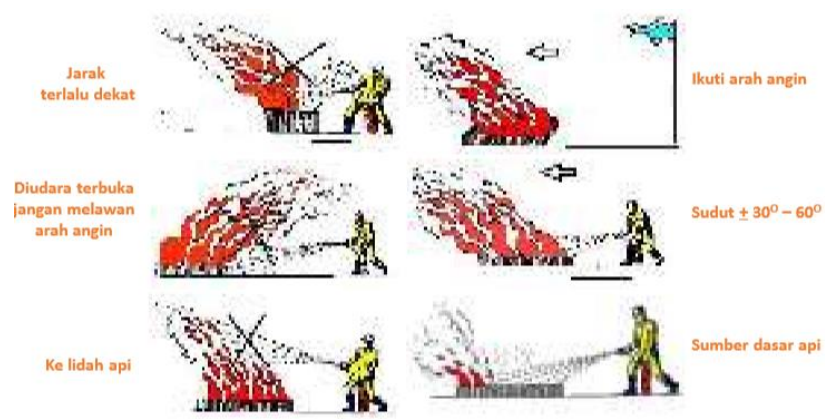

Gambar 8 Teknik pemadaman api dengan menggunakan APAR (sumber : handout training Basic Knowledge of Fire Protection)

\section{Bahan dan Metode}

Pengabdian Kepada Masyarakat (PKM) ini dilakukan dengan mengadakan Sosialisasi Upaya Pencegahan dan Penangggulangan Bahaya Kebakaran kepada Kepala Sekolah, guru-guru, staf administrasi, petugas sekolah dan seluruh siswa/siswi SLB dari segala jurusan dan tingkat. Pelaksana Pengabdian Kepada Masyarakat adalah dosen Universitas Balikpapan, Siska Ayu Kartika, S.T., M.MT dibantu dengan 5 orang mahasiswa dari Porgram Studi Teknik Mesin, yaitu Agung Prabasworo, Abdy Nugroho, Dawud Presetyo, Jafar Sidiq, dan Johan. Diagram Alir kegiatan PKM dapat dilihat pada gambar 9.

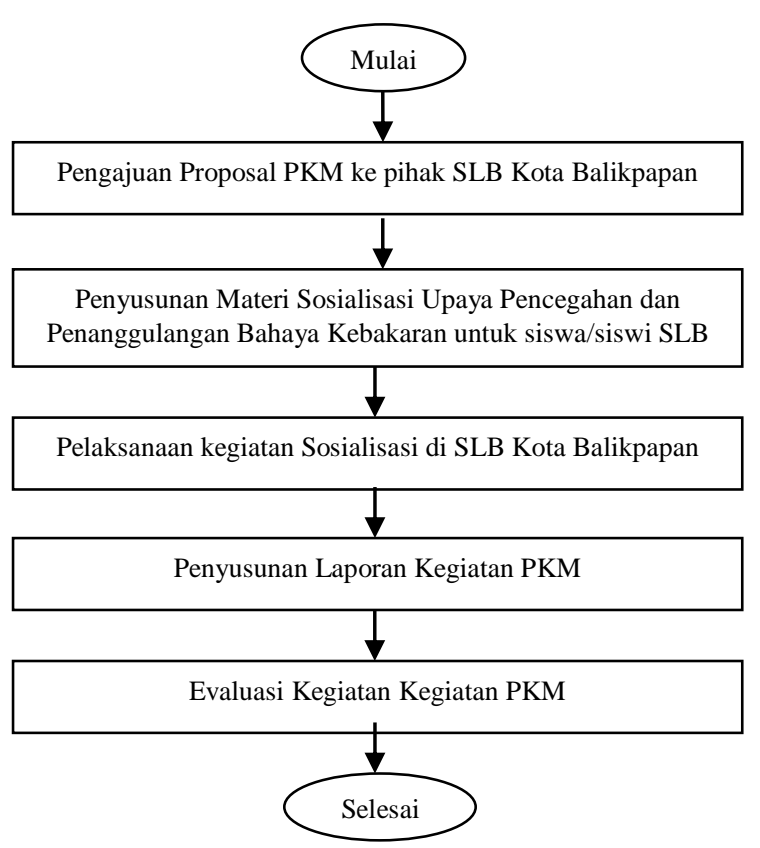

Gambar 9 Diagram Alir Kegiatan PKM 
Tabel 1.

Pelaksanaan Pengabdian Kepada Masyarakat (PKM) Tanggal

Kegiatan

$\begin{array}{ll}4 \text { April } 2017 & \begin{array}{l}\text { Pengajuan Proposal PKM ke pihak } \\ \text { SLB Kota Balikpapan }\end{array} \\ \text { 14 April 2017 } & \begin{array}{l}\text { Melakukan koordinasi dengan } \\ \text { Kepala SLB Kota Balikpapan } \\ \text { untuk menganalisa kebutuhan dan } \\ \text { materi untuk kegiatan sosialisasi }\end{array} \\ 26 \text { April 2017 } & \begin{array}{l}\text { Pelaksanaan Kegiatan Sosialisasi } \\ \text { Upaya Pencegahan dan }\end{array} \\ & \begin{array}{l}\text { Penanggulangan Bahaya Kebakaran } \\ \text { di SLB Kota Balikpapan }\end{array}\end{array}$

28April 2017 Evaluasi kegiatan pelaksanaan PKM bersama pihak SLB Kota Balikpapan

Kegiatan ini dilaksanakan di bulan April 2017, dengan detail kegiatan seperti terlihat pada Tabel 1. Tempat pelaksanaannya di Sekolah Luar Biasa (SLB) Balikpapan. Detail kegiatan dapat dilihat pada gambar 10, 11 dan 12 .

\section{Hasil dan Pembahasan}

Kegiatan yang telah dilakukan dalam program sosialisasi ini meliputi koordinasi dengan pihak sekolah, dalam hal ini Kepala Sekolah, para guru dan siswa-siswi yang berhubungan kegiatan ini.

Adapun rincian kegiatan yang telah dilakukan yaitu :

a. Menjelaskan definisi kebakaran dan bagaimana terjadinya api.

b. Menjelaskan apa saja penyebab terjadinya kebakaran.

c. Menjelaskan upaya apa saja yang dapat dilakukan untuk mencegah terjadinya kebakaran.

d. Menjelaskan bagaimana penanggulangannya jika terjadi kebakaran.

Total jumlah peserta yang mengikuti kegiatan sosialisasi ini sebanyak 96 orang, termasuk didalamnya siswa/siswi SLB dan guru-guru pendamping. Mengingat peserta sosialisasi ini adalah siswa/siswi Sekolah Luar Biasa (SLB), yang beberapa diantaranya memiliki keterbatasan dalam hal pendengaran, kemampuan bicara dan kemampuan mental yang terbatas, maka dalam penyampaian materi menjadi perhatian khusus dari tim pemateri. Kami tidak hanya menjelaskan secara verbal berdasarkan modul presentasi yang telah disiapkan, tetapi melengkapinya dengan gambar-gambar pendukung sehingga bagi mereka yang memiliki keterbatasan dalam pendengaran mendapatkan gambaran berupa visualisasi (baik berupa gambar maupun model/alat peraga) yang nyata.

Selain itu penjelasan yang kami berikan juga dengan menggunakan intonasi dan menunjukkan beberapa model/alat peraga pendukung yang dapat lebih memperjelas materi yang kami sampaikan, misalnya jenis-jenis kabel yang sesuai standar, sambungan listrik yang baik, instalasi listrik yang benar, dll.

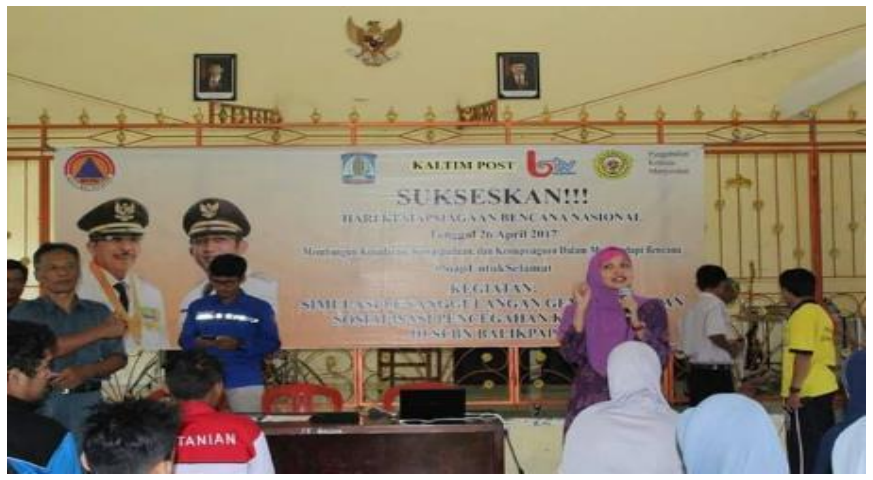

Gambar 10 Kegiatan pengarahan kepada guru dan siswa-siswa di SLB Kota Balikpapan (sumber : dokumentasi pribadi)

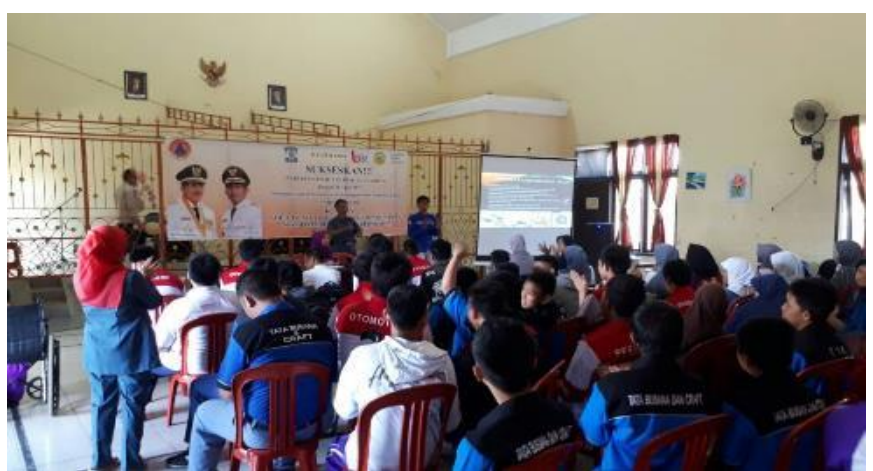

Gambar 11 Seluruh peserta siswa dan siswi SLB Kota Balikpapan dari berbagai jurusan

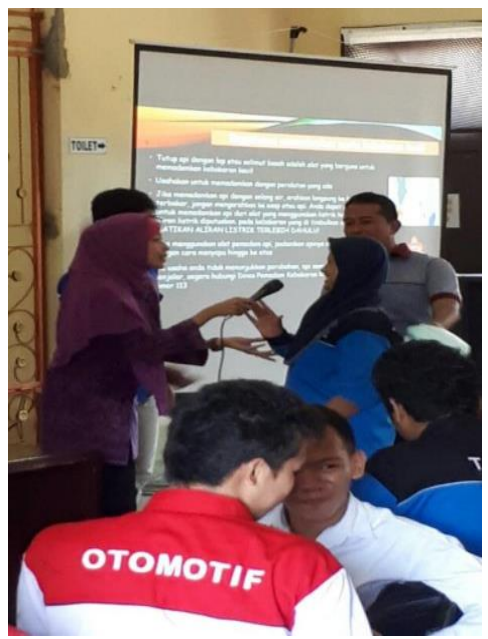

Gambar 12 Siswa/siswa SLB aktif mengikuti acara dalam sesi tanya jawab dan diskusi 


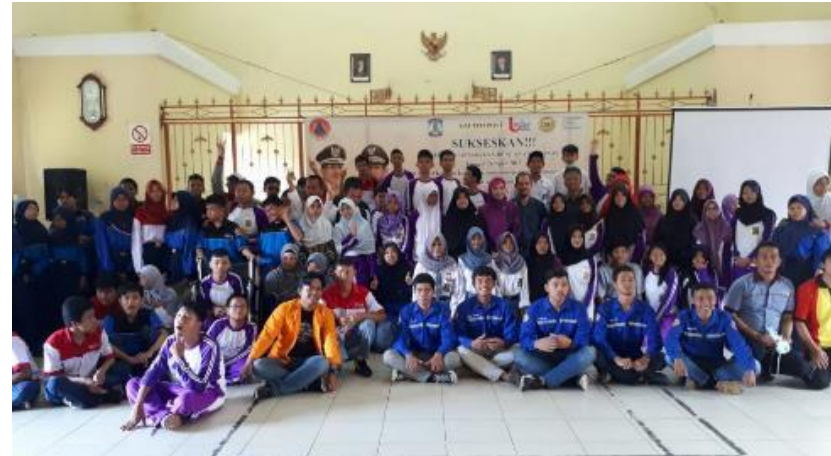

Gambar 13 Foto bersama peserta sosialisasi, kepala sekolah dan guru SLB Kota Balikpapan (sumber : dokumentasi pribadi)

Kegiatan Sosialisasi Upaya Pencegahan dan Penangggulangan Bahaya Kebakaran ini dapat terlaksana dengan baik, dan diharapkan dapat dilakukan secara berkala oleh mahasiswa untuk dapat menyegarkan dan mengulang materi yang telah didapat. Indikator yang dapat digunakan untuk mengukur keberhasilan pelatihan ini adalah:

a. Terlaksananya Sosialisasi Upaya Pencegahan dan Penangggulangan Bahaya Kebakaran sesuai dengan jadwal yang telah ditentukan.

b. Bertambahnya pemahaman siswa dan siswi di SLB kota Balikpapan, terutama mengenai upaya pencegahan dan penangggulangan bahaya kebakaran.

Kendala selama kegiatan sosialisasi ini adalah :

a. Terbatasnya kemampuan siswa dan siswi yang dapat mengikuti, karena beberapa diantaranya siswa/siswi tersebut memiliki beberapa keterbatasan fisiknya, misal memiliki keterbatasan dalam hal pendengaran, kemampuan bicara dan kemampuan mental yang terbatas, maka dalam penyampaian materi menjadi perhatian khusus dari tim pemateri dengan cara memberikan penjelasan dengan intonasi yang jelas, dan lebih lambat kecepatan penyampaiannya.

b. Pemahaman siswa-siswi yang tidak dapat langsung memahami sosialisasi yang diberikan dalam waktu singkat, sehingga untuk selanjutnya perlu dididskusikan dengan pihak sekolah ketersediaan waktu yang ada.

c. Pelaksanaan kegiatan sosialisasi yang langsung menggabungkan seluruh siswa/siswi dalam satu ruangan aula yang besar, sehingga dengan peserta yang terlalu banyak, menimbulkan suasana yang kurang kondusif. Sehingga untuk selanjutnya sebaiknya dibagi beberapa sesi dengan junlah peserta yang tidak terlalu banyak, maksimum 30 orang per sesi.

d. Terbatasnya ketersediaan APAR yang dapat digunakan untuk latihan cara penggunaan APAR. Sehingga penjelasan mengenai cara penggunaan
APAR hanya dilakukan dengan gambar, tanpa uji coba penggunaannya oleh pihak SLB Kota Balikpapan.

Sehingga sosialisasi seperti ini perlu dilakukan secara berkelanjutan agar program berjalan sesuai dengan harapan dan tujuan. Kami dari Tim perguruan tinggi Universitas Balikpapan akan selalu siap dalam membantu memberikan sosialisasi dam bentuk lain, secara lebih baik lagi, sehingga indikator keberhasilan program dapat segera terwujud dan kendala yang timbul dapat diminimalisir.

\section{Kesimpulan dan Saran}

Kesimpulan yang dapat diambil dari kegiatan pengabdian kepada masyarakat ini adalah kerjasama antar tim pengabdian kepada masyarakat Universitas Balikpapan dengan pihak SLB Kota Balikpapan sangat baik sehingga upaya untuk meningkatkan pemahaman para guru dan siswa/siswi mengenai upaya-upaya yang dapat dilakukan untuk pencegahan dan penanggulangan bahaya kebakaran dapat berjalan dengan baik. Oleh karena itu, diharapkan materi yang telah disampaikan dapat meningkatkan kesiapsiagaan / self-readiness siswa/siswi SLB terhadap bahaya kebakaran. Sehingga dapat dilakukan pencegahan sebelum terjadinya kebakaran.

Meskipun demikian ada beberapa kendala yang dihadapi, diantaranya : terbatasnya kemampuan pemahaman siswa dan siswi yang dapat mengikuti, karena kondisi masing-masing siswa/siswi dengan keterbatasan fisiknya, pemahaman siswa-siswi yang tidak dapat langsung memahami sosialisasi yang diberikan dalam waktu singkat, terlalu banyaknya peserta sosialisasi dan terbatasnya ketersediaan APAR yang dapat digunakan untuk latihan cara penggunaan APAR.

Saran yang dapat diberikan untuk pelaksanaan kegiatan pengabdian kepada masyrakat yang berkelanjutan adalah perlu adanya kajian lebih lanjut mengenai bentuk pelaksanaan PKM selanjutnya, dengan membagi peserta sosialisasi kedalam beberapa sesi agar lebih kondusif, memperbanyak alat peraga agar dapat memudahkan pemahaman siswa/siswi SLB. Selain itu perlu ada kajian lebih lanjut mengenai kemampuan peralatan penunjang komunikasi sistem peringatan dini, penunjang evakuasi, serta penunjang tanggap darurat yang ada disekolah-sekolah, melakukan evaluasi dan mengidentifikasi bagian persiapan dan perencanaan yang perlu diperbaiki dan ditingkatkan.

\section{Ucapan Terima Kasih}

Ucapan terima kasih kepada Merry K. Sipahutar, S.Pi., M.Si, Ph.D sebagai ketua LPPM Universitas 
Balikpapan, Dr. Ir. M. Isradi Zainal, M.T., M.H., M.M., DESS-CAAE, A. Eng., IPU sebagai Dekan Fakultas Teknologi Industri Universitas Balikpapan dan Mulyono, S.Pd., M.M. sebagai Kepala Sekolah Luar Biasa (SLB) Kota Balikpapan dan semua pihak yang telah membantu terlaksananya kegiatan ini.

\section{Daftar Rujukan}

Anonym. 2017. Handout Training Basic Knowledge of Fire Protection

Anonym. 2010. Materi Sosialisasi Pencegahan Bahaya Kebakaran di Perumahan TI. Departemen HRC/GNS, Total Indonesie, Balikpapan.

Ashari, M. L., Prastiwi, T., Annabila, A., Rahmadani, N., \& Kusuma, A. D. P. (2018). Sosialisasi Kebakaran Dan Penangannya Pada Siswa Sekolah Dasar Di Surabaya Guna Meningkatkan SelfReadiness Terhadap Bencana Kebakaran. Cakrawala Muslim, 21-24.

Darmana, T., Hidayat, S., Diantari, R. A., Ratnasari, T., Jumiati, \& Soewono, S. (2018). Sosialisasi Bahaya dan Penggunaan Listrik di Keluran Duri Kosambi, Cengkareng. Terang, 1(1), 96105.

Handoko, L., Ashari, M. L., Dermawan, D., Ari, M., Teknik, J., Kapal, P., ... Kapal, B. (2017). Edukasi Masyarakat dalam Upaya Pencegahan dan Penanggulangan Kebakaran pada Kawasan Pesisir. Seminar Master 2017 PPNS, 1509, 169-172.

Iraniana, R. (2009). Upaya Pencegahan dan Penanggulangan Bahaya Kebakaran sebagai Antisipasi Dini terhadap Bahaya Kebakaran di Pusdiklat Migas Cepu.

Janardana, I. G. N., Wijaya, I. W. A., Budiastra, N., \& Sukerayasa, W. (2018). Sosialisasi Keamanan Sistem Instalasi Listrik dan Hemat Energi di Banjar Tingkih Kerep Penebel Tabanan. Buletin Udayana Mengabdi, 17(4), 16-21.

Kementerian Tenaga Kerja dan Transmigrasi. (1980). PER.04/MEN/1980 Syarat-Syarat Pemasangan Dan Pemeliharaan Alat Pemadam Api Ringan.

Martanto, C., Aji, A., \& Parman, S. (2017). Kajian Kesiapsiagaan Masyarakat Dalam Menghadapi Bencana Kebakaran Di Kelurahan Kembangsari Kecamatan Semarang Tengah. Edu Geography, 1(2), 45-54-11.

Nasution, Y. (2012). Mitigasi Kebakaran melalui Masyarakat. Kesmas: National Public
Health Journal, 6(4), 179. https://doi.org/10.21109/kesmas.v6i4.97

Rahman, N. V. (2004). Kebakaran, Bahaya Unpredictible, Upaya Dan Kendala Penanggulangannya. Jurnal Fakultas Teknik Universitas Sumatera Utara, 1-18.

Supartini, E., Kumalasari, N., Andry, D., Susilastuti, Fitrianasari, I., Tarigan, J., ... Nugi, R. (2017). Latihan Kesiapsiagaan Bencana Nasional Membangun Kesadaran, Kewaspadaan, dan Kesiapsiagaan dalam Menghadapi Bencana. In N. Kumalasari, Susilastuti, \& J. Tarigan (Eds.), Buku Pedoman Latihan Kesiapsiagaan Bencana Nasional (Vol. 53). BPNB.

Tri, P. A., Aryani, S. L., Hidayati, L., Febriani, N., Lestari, T. A., Arifudin, ... Wahyuningsih, N. (2017). Peningkatan Pengetahuan dan Keterampilan Evakuasi Gempa Bumi dan Kebakaran pada Mahasiswa dan Karyawan PAI, KKI dan EPI Melalui Sosialisasi dan Mitigasi.

Yuniarti, E., Setiawati, M., \& Majid, D. A. (2018). Instalasi Listrik Yang Benar Dan Aman Dalam Upaya Mencegah Bahaya Kebakaran Akibat Konsleting Listrik Di Daerah Padat Penduduk Right And Secure Electrical Installation In Effort To Prevent Fire Hazards Due To Electrical Consleting In The Solid Population. Prosiding Seminar Nasional Penerapan IPTEKS, 4, 146-154.

https://alatpemadamapi101.com (diunduh tanggal 15 April 2017)

https://hsepedia.com/2018 (diunduh tanggal 15 April 2017) 